\title{
Analisis Branding Restoran Haka Dimsum Melalui Komunikasi Visual
}

\author{
Hokky Putra Pangestu, Wulan Purnama Sari \\ phanghokky@gmail.com,wulanp@fikom.untar.ac.id
}

Fakultas Ilmu Komunikasi Universitas Tarumanagara

\begin{abstract}
Digital era is a phenomenon that happening in the present and digital era is a technological advancement that is used by everyone. Haka Dimsum in conducting promotions in the digital era is the most important activity. The goal promotional activities carried out by Haka Dimsum is to trigger branding, it serves to provide an identity that has a characteristic of the product. To do the branding, Haka Dimsum creates contents in the form of photos and videos. Contents presented to the public, the contents have a role to convey the message by visual communication. This can be helped by using social media, especially Instagram because there are many users. This research discusses about, how to do branding analysis by Haka Dimsum with visual communication. This research method is done by way of case studies theory, which means learning more about a process in this research. This research aims to determine and describe the branding analysis conducted by Haka Dimsum through visual communication. The results of this research, can be seen with the interesting content like to tell a story and entertaining, can make audiences interested with the sales of product and interesting content is the most important part to do selling activity.
\end{abstract}

Keywords: branding, haka dimsum, instagram, social media, visual communication

\begin{abstract}
Abstrak
Era digital adalah fenomena yang terjadi pada masa kini. Era ini merupakan kemajuan teknologi yang dimanfaatkan oleh semua orang. Haka Dimsum dalam melakukan promosi di era digital merupakan kegiatan terpenting. Kegiatan promosi yang dilakukan Haka Dimsum mempunyai tujuan untuk branding, hal tersebut berfungsi untuk memberikan identitas agar mempunyai ciri khas terhadap produk. Untuk melakukan branding Haka Dimsum membuat konten berupa foto dan video, konten yang disajikan kepada khalayak mempunyai peran untuk menyampaikan pesan yaitu dengan cara komunikasi visual. Hal tersebut dapat dibantu dengan menggunakan media sosial terutama Instagram karena penggunanya banyak. Penelitian ini mempunyai tujuan untuk mengetahui dan menggambarkan analisis branding yang dilakukan Haka Dimsum melalui komunikasi visual. Metode penelitian ini dilakukan dengan cara studi kasus yang berarti mempelajari lebih lanjut tentang suatu proses dalam penelitian ini. Penelitian ini dilakukan agar mengetahui dan menggambarkan branding Haka Dimsum melalui komunikasi visual. Hasil penelitian ini dapat diketahui bahwa dengan konten yang menceritakan dan menghibur dapat membuat khalayak tertarik dengan produk yang dijual dan betapa pentingnya ketika menjual produk dengan menggunakan ide konten yang menarik.
\end{abstract}

Kata Kunci: branding, haka dimsum, instagram, komunikasi visual, media sosial

\section{Pendahuluan}

Fenomena yang dialami oleh masyarakat pada masa kini adalah kemajuan teknologi khususnya era digital apalagi jika dikaitkan dengan membangun suatu usaha sehingga dibutuhkannya branding. Menurut Diniarum (2019) branding adalah nama 
dan simbol dari merek tertentu sehingga terciptanya suatu ciri khas dan tema dari produk yang dibentuk. Kegiatan branding sangat berpengaruh jika dilakukan di media sosial karena penggunanya yang banyak, contohnya Instagram. Menurut Sholihah Afiffatus (2018) Instagram merupakan aplikasi yang mempunyai fitur membagikan foto dan video yang diunggah oleh pengguna yang bertujuan untuk berbagi kepada pengguna Instagram lain.

Dilansir Tekno kompas disebutkan oleh "Napoleoncat" yang merupakan platform website analisis media sosial dan pengembangan brand di media sosial disebutkan bahwa pengguna Instagram di Indonesia berusia 18-24 tahun merupakan pengguna yang paling banyak yaitu dengan presentase $37,3 \%$ dan kedua nya adalah yang berusia 25-34 tahun dengan total presentase 33,9\%, Pertiwi Wahyunanda Kusuma (2019). Instagram saat ini sangat mempengaruhi pengembangan suatu bisnis, dan Haka Dimsum memanfaatkan Instagram untuk branding dan mengandalkan komunikasi visual.

Menurut Asih (2012) komunikasi visual menyampaikan pesan dengan cara penglihatan kepada individu lain dan sehingga ketika menyediakan gambar atau konten, hal tersebut adalah penyampaian pesan dan yang menerima adalah setiap individu yang melihat konten atau gambar tersebut. Komunikasi visual yang disampaikan yaitu dengan mengunggah konten berupa foto dan video di Instagram. Hal ini dimanfaatkan oleh restoran Haka Dimsum untuk melakukan iklan yang menarik dan memberikan pesan komunikasi visual yang menunjukan citra diri dari brand tersebut.

Berdasarkan uraitan latar belakang maka ditetapkanlah "Analisis Branding Haka Dimsum melalui komunikasi visual" sebagai judul penelitian ini. Tujuan dari penelitian ini agar mengetahui dan menggambarkan branding yang dilakukan oleh Haka Dimsum melalui komunikasi visual. Penelitian ini mendapatkan sebagian informasi tentang branding berdasarkan penelitian terdahulu yaitu Stevani dan Widayatmoko (2017) yang membahas kepribadian dan komunikasi Susi Pudjiastuti dalam membentuk personal branding sehingga lebih terfokus kepada subjek. Perbedaan dari penelitian tersebut adalah branding yang ditujukan kepada restoran Haka Dimsum. Penelitian ini lebih berfokus kepada objek.

\section{Metode Penelitian}

Pendekatan penelitian yang digunakan oleh penulis dalam menganalisis branding Haka Dimsum melalui komunikasi visual adalah pendekatan kualitatif dan metode yang digunakan adalah studi kasus. Menggunakan metode studi kasus karena metode penelitan dilakukan secara mendalam dan berhubungan dengan pendekatan kualitatif, Perlunya studi kasus karena penelitian ini ingin membahas lebih dalam terhadap persoalan tertentu seperti alasan dan ide dari key informan dan informan seperti pembeli dan pengikut Instagram Haka Dimsum.

Penulis menargetkan subjek penelitian yang merupakan penjual (owner) dan pembeli yang terdiri dari Kenny Pranata sebagai pemilik restoran, dan pembeli yang terdiri dariKaren Mirabel, Mellinda Hoza, Jefferson Putra. Penulis juga meneliti objek penelitian yaitu, proses branding yang berkaitan dengan komunikasi visual melalui suatu konten yang akan diunggah di Instagram. 


\section{Hasil Temuan dan Diskusi}

Restoran Haka Dimsum yang didirikan sejak Desember tahun 2018 ini, memerlukan strategi agar calon konsumen mengetahui dan mengerti produk yang dijual oleh pemilik restoran. Dalam kegiatan branding yang dilakukan oleh Haka Dimsum, restoran tersebut tidak hanya menampilkan foto makanan, tetapi juga dengan membuat suatu penyajian konten yang bisa dinikmati oleh calon konsumen yang bertujuan agar terlihat lebih unik dan mempunyai ciri khas tersendiri dalam branding.

Menurut pemilik Haka Dimsum, membuat suatu konten yang menarik adalah kegiatan yang sangat penting. Kegiatan branding ini berhubungan dengan brand images, Jika brand images dibentuk dan mendapatkan hasil yang baik maka pengenalan produk di mata masyarakat akan semakin luas dan baik. Hal positif bisa terjadi karena brand Haka Dimsum berhasil dalam membuat suatu konten yang menghasilkan pandangan yang positif dan menjadi produk yang diterima oleh masyarakat.

Haka Dimsum sangat menyadari bahwa media sosial Instagram sangat diperlukan, hal tersebut karena memiliki tujuan untuk menjalin suatu komunikasi yang baik terutama komunikasi visual untuk pencapaian suatu transaksi jual dan beli yang dilakukan Haka Dimsum. Haka Dimsum juga menggunakan fitur Instagram seperti Instagram stories. Instagram merupakan peran penting karena mempunyau pengguna yang banyak dan mudah untuk dicapai.

"Saya hanya menggunakan Instagram karena aplikasi tersebut mempunyai pengguna yang banyak sehingga lebih mudah untuk dicapai." (hasil wawancara dengan Kenny Pranata, pemilik restoran Haka Dimsum.) Berdasarkan data Instagram, tercatat sebanyak tak kurang dari 45 juta orang Indonesia merupakan pengguna media sosial yang aktif dan pembuat konten dalam fitur Instagram stories terbanyak di dunia. Adi, Aghni \& Ali Hidayat. (2017)

Gambar 1. Instagram Stories Haka Dimsum

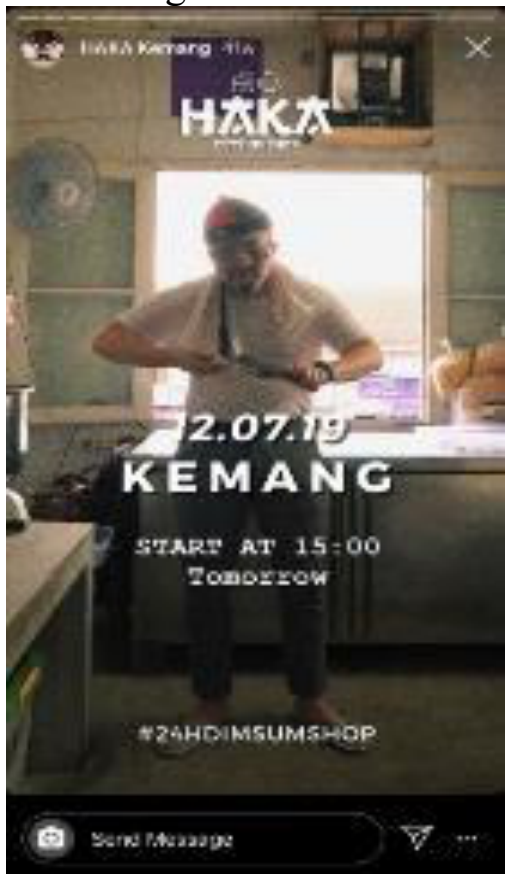

Sumber: Highlights Story Akun@Hakadimsum 
Hokky Putra Pangestu, Wulan Purnama Sari: Analisis Branding Restoran Haka Dimsum Melalui Komunikasi Visual

Haka Dimsum juga mempunyai kunci dalam membuat suatu konten untuk menarik perhatian konsumen, yaitu harus relate atau berhubungan dengan apa yang dirasakan atau dialami oleh konsumen dalam sehari-hari. Hal tersebut penting agar penerima komunikasi visual lebih mudah memahami dan mengerti perasaan yang dialami oleh khalayak. Misalnya kejadian yang pernah dialami oleh masyarakat di wilayah DKI Jakarta yaitu di Bulan Januari 2020 terjadinya banjir. Banyak masyarakat yang terjebak di dalam rumah dan tidak bisa membeli makanan dari luar. Dari kejadian tersebut, muncul lah ide konten oleh Haka Dimsum yaitu dengan memotret karyawan Haka Dimsum sambil membawa menu makanan dimsum mereka di atas perahu karet.

Konten tersebut diunggah di Instagram Haka Dimsum dan menarik perhatian masyarakat secara luas dan menjadi viral.Akhirnya foto tersebut mendapatkan likes sebanyak 17,170 dengan komentar sebanyak 330. Dari konten tersebut, Haka Dimsum bertujuan untuk menginformasikan kepada pelanggan Haka Dimsum bahwa mereka tetap melayani pelanggan walaupun sedang terjadi banjir.

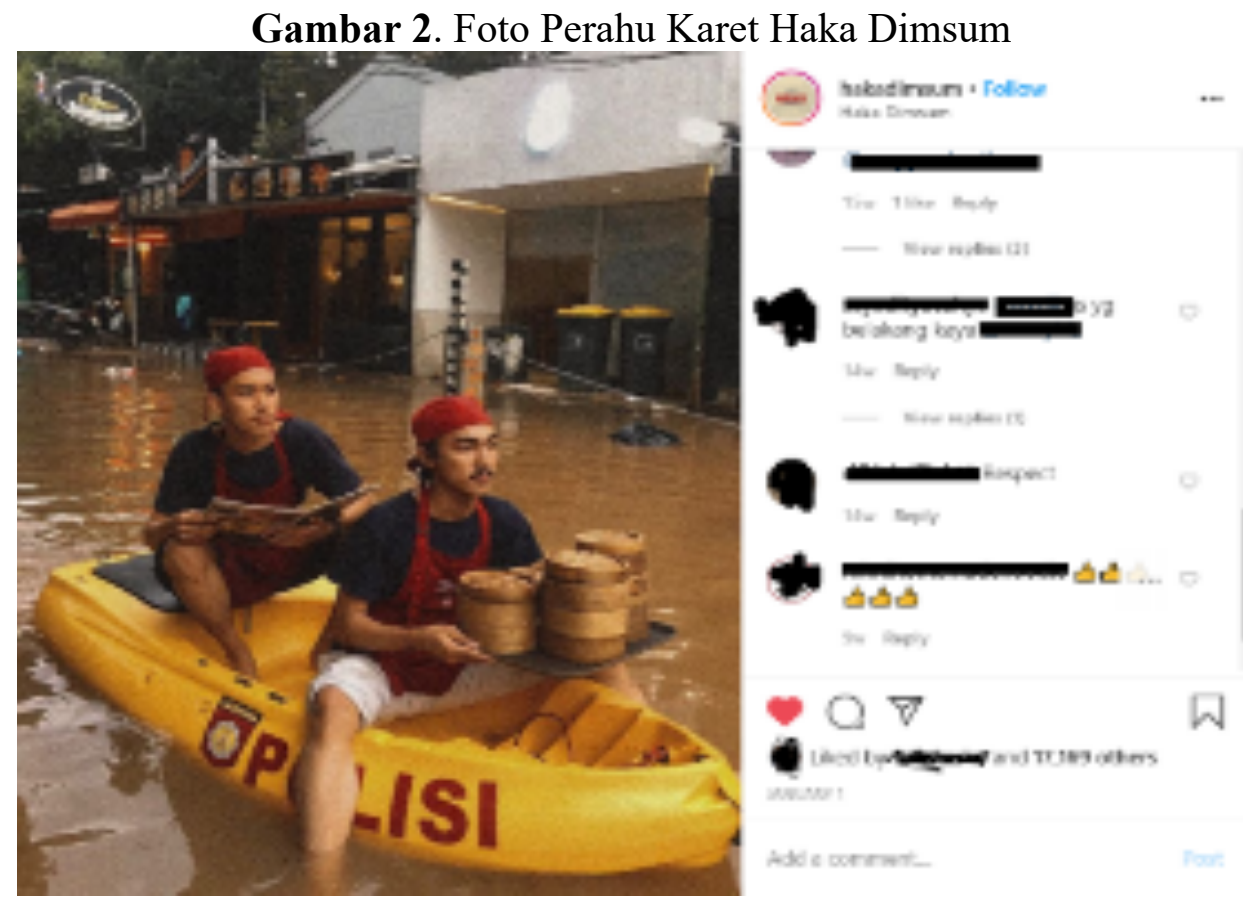

Sumber: Instagram Haka Dimsum

Untuk tujuan branding Haka Dimsum selalu mempunyai konsep cerita ketika membuat konten dalam bentuk video. Konsep tersebut adalah "Haka senior dengan Haka Junior". Diceritakan bahwa dalam konten tersebut Haka senior telah membuat dimsum sudah sejak lama dan ingin diturunkan ke generasi bawahnya. Konten tersebut dibuat dengan kualitas yang tinggi dan mempunyai arti cerita yang dapat dimengerti dan dinikmati oleh khalayak. "betul untuk branding, pada pertama kali menggunakan Haka untuk meyakinkan customer bahwa kami ahli dalam membuat dimsum dan dengan cara si Haka dari kecil hingga besar sudah ahli membuat dimsum dan mempunyai tujuan untuk memiliki toko yang tersebar." (hasil wawancara dengan Kenny Pranata, pemilik restoran Haka Dimsum.)

Tujuan lain dari pemilik restoran Haka Dimsum dalam membuat konten tersebut adalah agar konsumen mendapatkan kepercayaan bahwa dimsum yang dibuat 
oleh restoran tersebut mempunyai rasa yang enak dan meyakinkan mereka bahwa Haka Dimsum sudah ahli dalam membuat dimsum melalui cerita dari Haka kecil hingga Haka besar yang kemudian diturunkan ke anaknya yang mempunyai cita-cita membuka toko restoran tersebut dimana-mana.

Gambar 3. Konten Haka Senior dengan Haka Junior

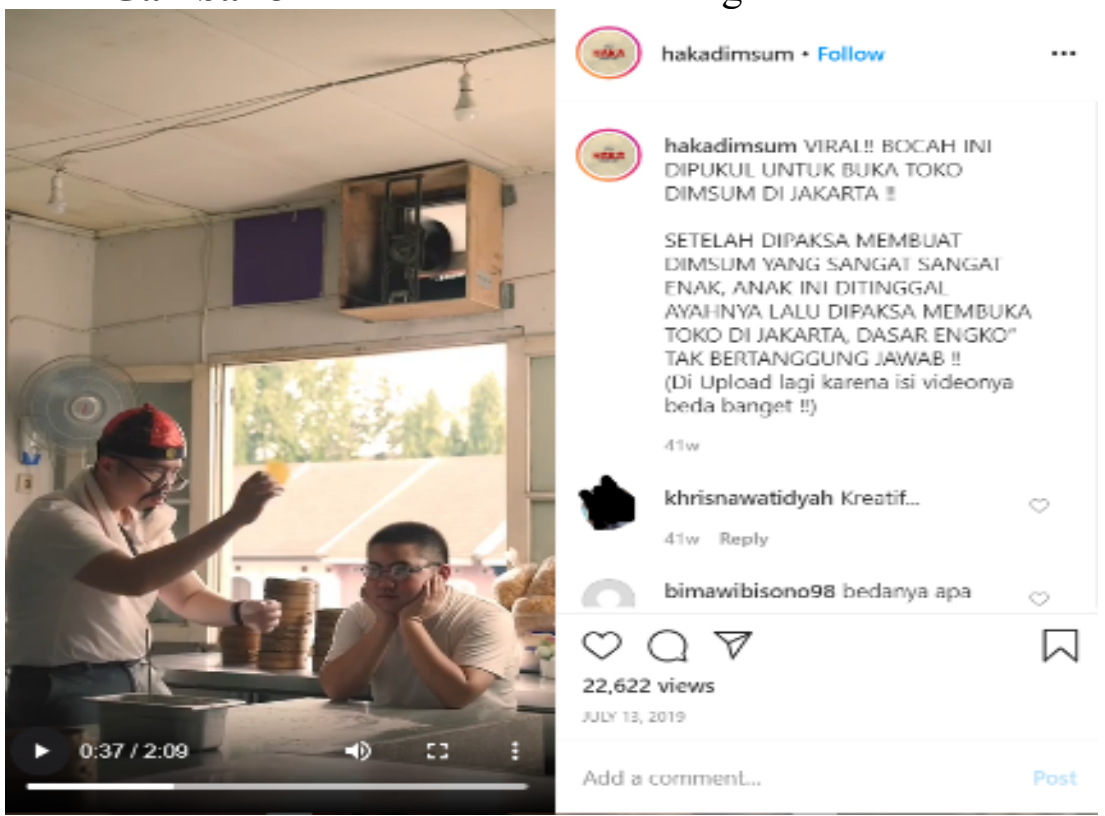

Sumber: Instagram Haka Dimsum

Haka Dimsum gemar mengunggah konten berupa foto yang diolah agar unik dan terlihat menarik. Hal tersebut merupakan moto yang diciptakan owner Haka Dimsum dalam membuat konten yaitu agar tidak terlalu membuat konten yang serius, tetapi membuat konten yang membuat khalayak atau calon konsumen tersenyum. Hal tersebut bagi owner agar terlihat lebih casual.

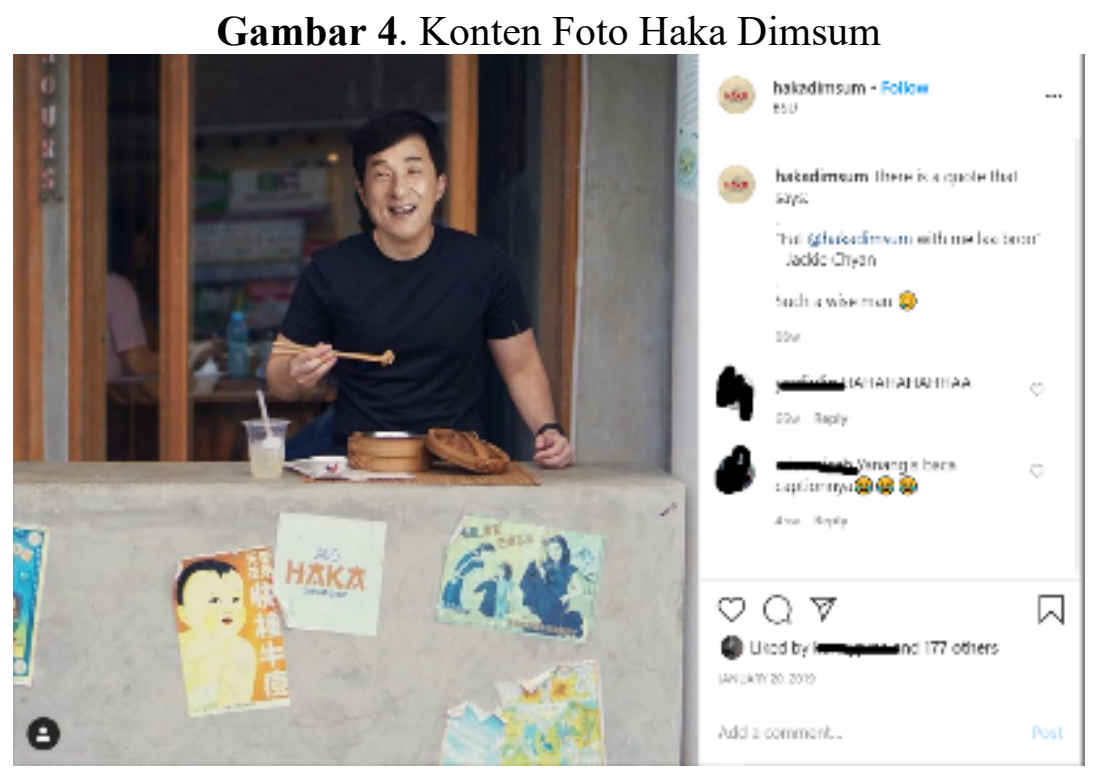

Sumber: Instagram Haka Dimsum 
Hokky Putra Pangestu, Wulan Purnama Sari: Analisis Branding Restoran Haka Dimsum Melalui Komunikasi Visual

Owner Haka Dimsum mempunyai kepercayaan dalam memproduksi suatu konten yang baik karena konten yang dibuat bertujuan untuk memiliki hubungan langsung dengan konsumen, maka perhatian dari mereka akan lebih besar dan nama Haka Dimsum akan lebih mudah untuk diingat. Konten Haka senior dan Haka Junior adalah salah satu contoh konten video yang dimengerti oleh khalayak. Haka Dimsum tidak mempunyai tim khusus untuk dokumentasi seperti foto maupun video. Hal tersebut menjadi tantangan bagi owner sekaligus otak dari ide yang dikeluarkan karena hasil yang dibuat oleh videographer terkadang tidak seakurat dengan bayangan sang pemilik restoran. Kesulitan tersebut bisa berakibat konsumen tidak mengerti konten yang dibuat karena penyampaian komunikasi visual tersebut tidak maksimal.

Hasil akhir dari tujuan Haka Dimsum dalam membuat suatu konten video tidak hanya menyajikan dengan kualitas video yang bagus, tetapi juga dapat dimengerti dan penyampaian pesan secara komunikasi visual dapat diterima oleh khayalak. Haka Dimsum mempunyai prinsip bahwa konten yang dihasilkan dengan kualitas tinggi dan diunggah di Instagram harus mempunyai kualitas dalam pelayanan, kualitas rasa yang sebanding dengan konten-konten tersebut. Ketiga informan yang terdiri dari Karen Mirabel, Mellinda Hoza, Jefferson Putra mempunyai pendapat yang hamper sama, yaitu konten mereka sangat kreatif dan tidak selalu memperlihatkan menu makanannya di Instagram sehingga tidak membosankan tetapi jelas apa yang dijual oleh restoran tersebut. Ketiga informan setuju bahwa setiap ingin mengunjungi atau ketika sudah beda di restoran Haka Dimsum, mereka teringat akan konten yang diunggah oleh Haka Dimsum di Instagram. Ketiga informan mengakui tertarik karena restoran tersebut dibuka selama 24 jam.

"Saya memfollow Instagram Haka Dimsum, konten mereka menarik dan yang saya ingat bahwa mereka membuat konten yang terdapat anak kecil yang membuat dimsum dan hal tersebut adalah ide yang unik dan lucu." (hasil wawancara Mellinda Hoza, konsumen dan pengikut akun Instagram restoran Haka Dimsum). Ketiga informan setuju bahwa pemegang Instagram Haka Dimsum ramah dan menghibur. Salah satu informan yaitu Mellinda Hoza menyebutkan bahwa Haka Dimsum menyebut "Haka" sebagai individu dan teman bagi konsumen. Ketiga informan setuju bahwa logo Haka Dimsum selaras dengan tema restoran tersebut.

Gambar 5. Logo Haka Dimsum

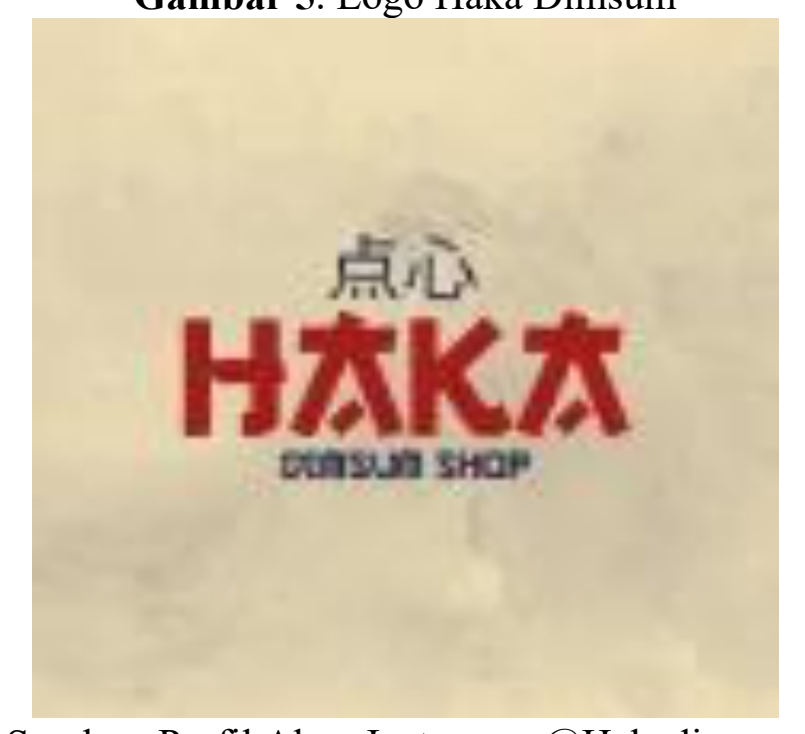

Sumber: Profil Akun Instagram @Hakadimsum 
Kedua informan yaitu Mellinda Hoza dan Karen Mirabel setuju bahwa konten "Standar Kebersihan Haka Dimsum" membuat mereka percaya untuk memesan makanan selama pandemi Covid-19. Informan yang bernama Jefferson Putra tidak setuju akan pendapat tersebut karena apapun yang dilakukan oleh pihak restoran dalam segi konten seperti "Standar Kebersihan Haka Dimsum" tidak tau apa akan tetap dijalani atau tidak sehingga tidak terlalu berpengaruh bagi informan tersebut.

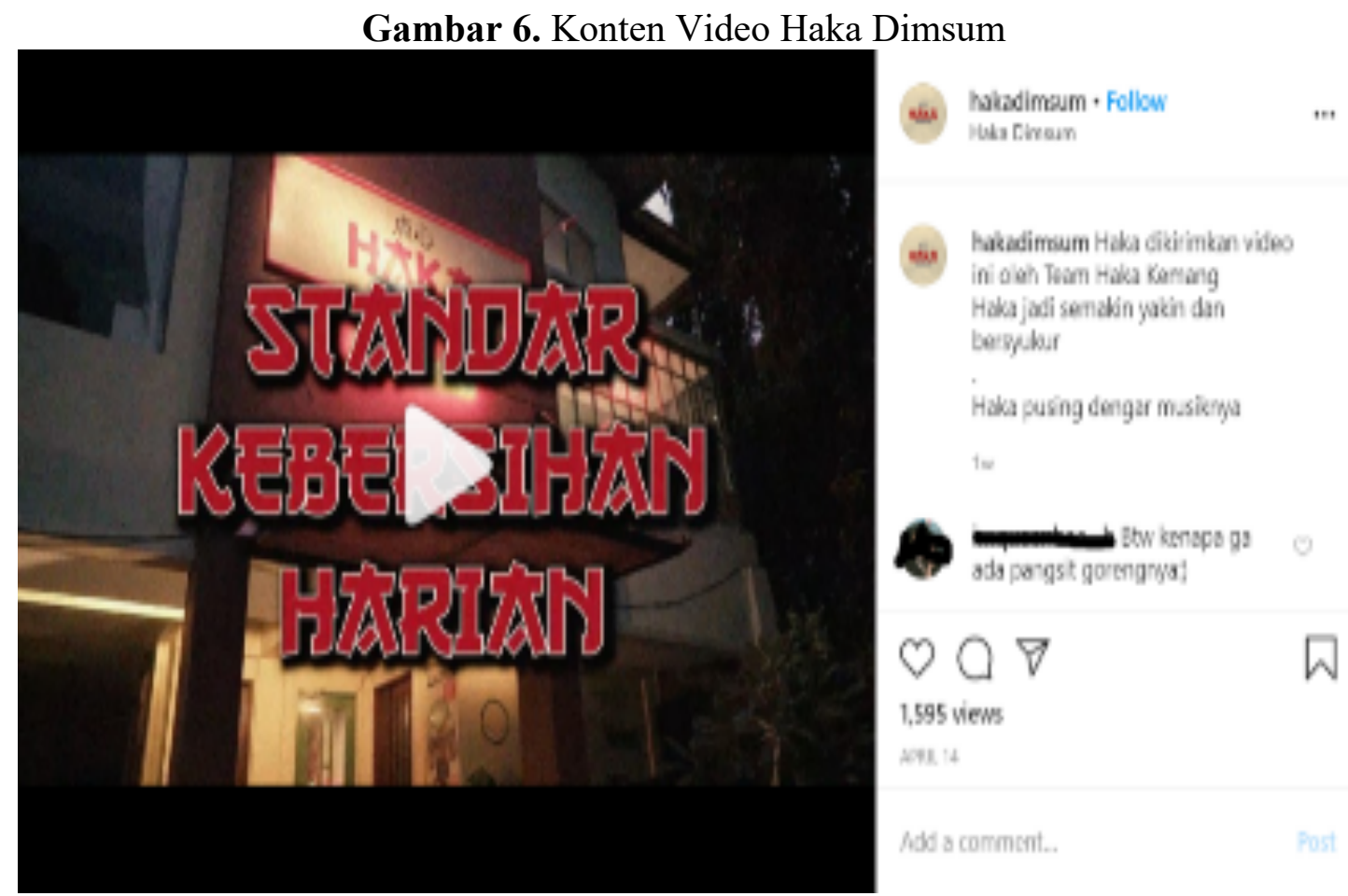

Sumber: Instagram Haka Dimsum

Kedua Informan yang terdiri dari Mellinda Hoza dan Karen Mirabel sangat setuju bahwa konten yang disajikan di Instagram kepada khalayak dan branding yang dilakukan sebanding dengan kualitas yang diberikan secara langsung kepada konsumen. Informan yang bernama Jefferson Putra sedikit setuju karena informan tersebut berpendapat bahwa restoran Haka Dimsum merupakan kategori halal sehingga kualitas rasa tidak maksimal tetapi masih status yang layak. Jefferson Putra mengungkapkan bahwa kualitas pelayanan masih sebanding dengan branding restoran Haka Dimsum.

\section{Simpulan}

Berdasarkan hasil penelitian, kesimpulan bahwa konten merupakan variabel terpenting jika mengembangkan dan mempertahankan branding. Hal berbau konten yang menarik mempunyai fungsi untuk menarik perhatian khayalak, konten yang biasanya dalam bentuk foto atau video mempunyai tujuan untuk penyampaian suatu pesan dalam bentuk visual atau lebih tepatnya komunikasi visual. 
Hokky Putra Pangestu, Wulan Purnama Sari: Analisis Branding Restoran Haka Dimsum Melalui Komunikasi Visual

Konten yang mempunyai tujuan untuk menyampaikan pesan secara visual sangat cocok dilakukan di media sosial. Media sosial mempunyai pengguna yang banyak dan media sosial yang paling cocok adalah Instagram karena untuk penyajian konten dalam bentuk foto atau video sudah terpenuhi. Haka Dimsum telah melakukannya dengan baik yaitu dalam membuat dan menyajikan konten menarik kepada khalayak. Haka Dimsum juga telah membuat suatu ciri khas pada restorannya terutama dari segi konten. Konten-konten yang dibuat Haka Dimsum ditujukan untuk penyampaian pesan secara komunikasi visual. Branding yang dilakukan Haka Dimsum juga mempunyai ciri khas dan pembeli mengakuinya.

\section{Ucapan Terima Kasih}

Peneliti ingin mengucapkan banyak terima kasih kepada seluruh narasumber penulis yang telah memberikan informasi terkait dengan penelitian ini. Lalu kepada keluarga, sahabat, dan teman - teman penulis yang ikut menyemangati dan memberikan banyak dukungan dalam penulisan skripsi ini. Peneliti mengucapkan terima kasih kepada key informan yaitu pemilik restoran Haka Dimsum karena telah bersedia menjadi narasumber. Berterima kasih juga kepada keluarga dan sahabat yang memberi semangat untuk menyelesaikan penelitian ini.

\section{Daftar Pustaka}

Adi, Aghni \& Ali Hidayat. (2017, 26 Juni). 45 juta pengguna Instagram Indonesia pasar terbesar di Asia. Retrieved April 24, 2020. Tempo. https://bisnis.tempo.co/read/894605/45-juta-pengguna-instagram-indonesiapasar-terbesar-di-asia

Asih, Anik Budi. (2012). Pengaruh komunikasi visual puteri body mist cologne fashionista terhadap keputusan pembelian. Skripsi Universitas Islam Negeri Sultan Kalijaga Yogyakarta. Februari 172020 Terarsip di: http://digilib.uin-

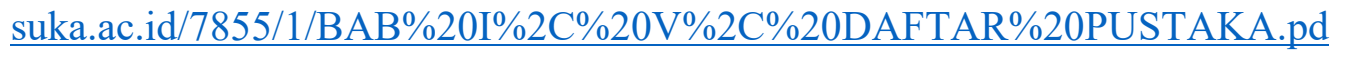
$\underline{\mathrm{f}}$

Diniarum, FiniNur Aulidia. (2019), STRATEGI BRANDING PT. BERKAH CATERING NUSANTARA DI SIDOARJO. Skripsi Universitas Islam Negeri Sunan Ampel Surabaya. Februari 17 2020. Terarpsi di: http://digilib.uinsby.ac.id/29984/3/Fini\%20Nur\%20Aulidia\%20Diniarum_B06 215016.pdf

Pertiwi, Wahyunanda Kusuma. (2019, 23 Desember). Sebanyak inikah Jumlah Pengguna Instagram Di Indonesia? Retrieved Maret 12, 2020. Kompas. https://tekno.kompas.com/read/2019/12/23/14020057/sebanyak-inikah-jumlahpengguna-instagram-di-indonesia

Sholihah, Afiffatus. (2018). Penggunaan Instagram Melalui Media Promosi (studi Deskriptif kualitatif pada Produk Teh Thailand Pikameame di Yogyakarta) Skripsi Universtias Islam Negeri Sunan Kalijaga, Yogyakarta, Indonesia. Maret 122020 Terarsip di: http://digilib.uin-suka.ac.id/31929/1/14730003_BABI_IV_DAFTAR-PUSTAKA.pdf 
Vol. 5, No. 1, Maret 2021, Hal 36-44

Stevani., \& Widayatmoko. (2017). Kepribadian Dan Komunikasi Susi Pudjiastuti Dalam Membentuk Personal Branding. Jurnal Komunikasi. Terarsip di: https://journal.untar.ac.id/index.php/komunikasi/article/view/225/644 